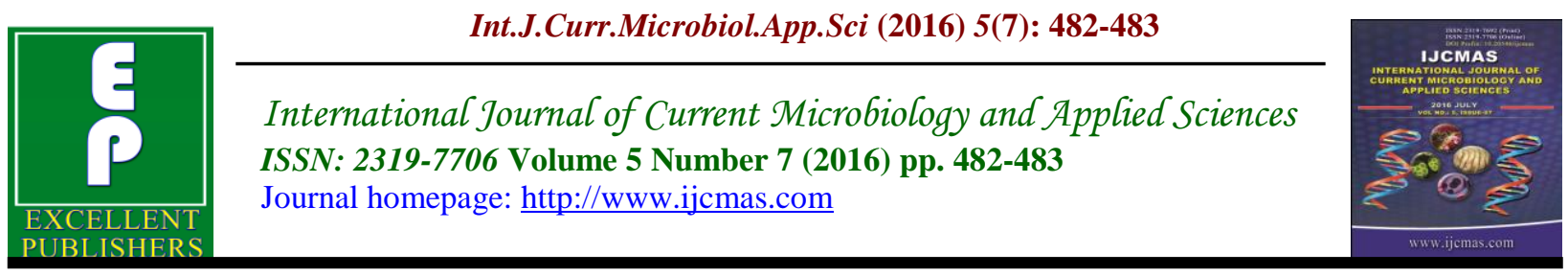

Letter to Editor

http://dx.doi.org/10.20546/ijcmas.2016.507.052

\title{
Heterotrophic Plate Count: A Doubtful Microbial Indicator for Monitoring the Potability of Water in Tropics
}

\author{
Pendru Raghunath* \\ Department of Microbiology, School of Medicine, Texila American University, Guyana \\ *Corresponding author
}

WHO considers that drinking water should be suitable for human consumption and for all usual domestic purposes including personal hygiene. Diverse regulatory agencies adopt similar definitions. Drinking water should therefore be suitable for consumption, washing/showering and domestic food preparation. In many areas groundwater is polluted by human activities. If groundwater becomes polluted, it will no longer be safe to drink. Potable drinking water is premium even in metropolitan areas in developing and underdeveloped countries. Still people from many places in India depend on well or pond water for drinking. It is impossible for the water delivered through any piping system or well water or pond water to be totally free of bacteria. Hence, it is necessary to have a continuous However, the presence of pathogenic bacteria in water is sporadic and erratic, levels are low, and the isolation and culture of these bacteria is not straightforward. There are several indicators available to monitor the potability of water. Hence, it is important to depend on the other microbial indicators of faecal contamination. Two most commonly used indicators are coliform count (total coliforms and Escherichia coli) and standard plate count, also called Heterotrophic plate count (HPC).
Other terms that have been used to describe HPC in water include "total viable count", "'plate count', “total bacterial count", "'aerobic mesophilic viable count', and “'autochthonous flora'.

All bacteria requiring organic nutrients for growth are called as heterotrophic bacteria. All the available methods enumerate only a fraction or subpopulation of heterotrophic bacteria in water samples. HPC of a water sample depends on method used, media composition, temperature of incubation, and incubation time. Health agencies like the EPA and World Health Organization (WHO) have recommended guidelines for drinking water. There is a common belief that an increase in HPC is an indirect evidence for increase in coliform count (Geldreich et al., 1972; Goshko et al., 1983). But there are also reports stating the absence of association between HPC and coliform count (Edberg and Smith, 1989).

I have been working as a Microbiologist since 15 years. We routinely analyze water samples (from different sources like well water, borewell water and municipality water supplied through piping system) for potability. Microbiological analysis of water samples will be started as soon as possible 
after collection to avoid unpredictable changes in the microbial population (Gaudy, 1998). HPC of water samples were estimated by spread plate method using Heterotrophic Plate Count Agar (Hi media Pvt. Ltd, Mumbai). Total and faecal coliform (E. coli) counts were estimated by most probable number (MPN) method using double and single strength MacConkey liquid media (Britton and Greeson, 1987; APHA, 1998). From positive tubes, subcultures were made onto eosin methylene blue (EMB) agar and typical colonies of $E$. coli were further identified by biochemical tests. Many of the water samples (more than $30 \%$ ) yield high HPCs i.e. more than $10^{3}$ $\mathrm{CFU} / \mathrm{ml}$ but coliform count is nil. In tropics the average room temperature is $25-30^{\circ} \mathrm{C}$ and bacteria present in water multiply fast and reach such high levels. High HPCs indicate ideal conditions for bacterial regrowth and should be corrected. An increase in HPC in finished water can indicate a problem with water treatment or a change in quality of the water source, prior to treatment. When HPC levels leaving the treatment plant are acceptable, but levels in the distribution system are above baseline levels, regrowth may be occurring in the distribution system. Most of the bacteria which are responsible for high HPC are commensals. Hence, in tropics it is not possible to predict the potability of water samples based on HPC.

Inspite of variable results obtained from different laboratories around the globe, heterotropic bacteria were used as surrogate indicators because of a lack of specific detection methods for the enteric organisms.
However, with recent advancements in specific methodologies, such as availability of selective media, molecular techniques such as PCR and hybridization based methods for detection of $E$. coli and other enteric pathogens, the applicability of HPC in the treatment and delivery of drinking water in tropics needs to be addressed.

\section{References}

American Public Health Association (APHA). 1998. and Water Pollution Control Federation. 1998. Standard methods for the examination of water and waste water 20 th ed, Washington D.C.

Britton. L.J., Greeson, P.E. 1987. Methods for collection and analysis of aquatic biological and microbiological samples; US Geological survey techniques of waterresources investigations, book 5, chap., A4, 363-403.

Edberg, S.C., and Smith, D.B. 1989. Absence of association between total heterotrophic and total coliform bacteria from a public water supply. Appl Environ. Microbiol., 55: 380-384.

Gaudy, F.A. 1998. Microbiology for environmental scientists and engineers. London: McGraw Hill International Book Company.

Geldreich, E.E., Nash, H.D., and Reasoner, J. et al. 1972. The necessity of controlling bacterial populations in potable waters: community water supply. J. Am. Water Works Assoc., 596-602.

Goshko, M.A., Minnigh, H.A., and Pipes, W.O. et al. 1983. Relationships between standard plate counts and other parameters in water distribution systems. J. Am. Water Works Assoc., 568-571.

\section{How to cite this article:}

Pendru Raghunath. 2016. Heterotrophic Plate Count: A Doubtful Microbial Indicator for Monitoring the Potability of Water in Tropics. Int.J.Curr.Microbiol.App.Sci. 5(7): 482-483. doi: http://dx.doi.org/10.20546/ijcmas.2016.507.052 